\title{
Identification and documentation of Ethno- veterinary remedies used by Afar Pastoralists for the treatment of Camel diseases in Ethiopia
}

Fikadu Gutema ( $\square$ fikadu881@gmail.com )

Department of Animal health research,Werer Agricultural research center, Ethiopian Institute of Agricultural Research, PO.BOx 2003, Werer, Ethiopia

\section{Weldegebrial G.Aregawi}

Department of Animal health research,Werer Agricultural research center, Ethiopian Institute of Agricultural Research, PO.BOx 2003, Werer, Ethiopia

Juhar Tesfaye Bekele

Department of Animal health research,Werer Agricultural research center, Ethiopian Institute of Agricultural Research, PO.BOx 2003, Werer, Ethiopia

Abel sorsa Geletu

Department of Animal health research,Werer Agricultural research center, Ethiopian Institute of Agricultural Research, PO.BOx 2003, Werer, Ethiopia

\section{Research Article}

Keywords: Afar, Camel, Ethnoveterinary, Herbal remedies, Pastoralist, Traditional healers

Posted Date: April 27th, 2021

DOI: https://doi.org/10.21203/rs.3.rs-454901/v1

License: (c) (1) This work is licensed under a Creative Commons Attribution 4.0 International License. Read Full License 


\title{
Identification and documentation of Ethno-veterinary remedies used by Afar Pastoralists for the treatment of Camel diseases in Ethiopia
}

Fekadu Gutema ${ }^{* 1,2}$, weldegebriel G/Egzihabher ${ }^{1,3}$, Juhar Tesfaye ${ }^{1}$, Abel Sorsa ${ }^{1}$

1-Werer Agricultural research center, department of Animal health research, PO Box:2003

2-Holeta Agricultural research center, department of Animal health research, PO Box:31

3-Mehoni Agricultural research center, department of animal health research, PO Box:71

Corresponding Author: fikadu881@gmail.com

\begin{abstract}
Ethnoveterinary medicine is a scientific term for traditional animal health care that encompasses knowledge, belief, practice and skill of the community used for curing diseases and maintaining health of animals. A cross-sectional study was conducted using semi-structured questionnaires from September 2016 to August 2017 to gather information on the knowledge, practice and skill of the pastoralists and traditional healers about the importance and application of Ethnoveterinary medicine. Moreover, this study was conducted with the objectives of identification and documentation of major ethno-veterinary medicinal plants commonly used to treat camel aliments in Afar region. A total of 146 traditional healers and pastoralists were interviewed for baseline and reliable information about Ethno-veterinary medicinal practice in Afar region. Accordingly, $99.3 \%$ of the respondents were men in which $66.44 \%$ of them were in the age range of 45-60. Majorities (76.02\%) of the information's concerning EVM were obtained from the elders among which $84.93 \%$ responded that the overall EVM practice and status in pastoral society of Afar is decreasing. A total of 710 plant species supposed to have medicinal property were recommended by pastoralists to be used for the treatment of 49 different animal diseases. Among 64 plants specimen collected, Balanites aegyptia, Cissus rotundifolia (Forssk.) Vahl, Cadaba rotundifolia Forssk, Solanum sp, Acalypha indica L and Tamarix aphylla (L.) Karsts were the commonly used plant species with high fidelity value. Concerned with plant parts used, leaf $(20.5 \%)$ was the most frequently used plant parts followed by root (19.4\%), fruit (14.4\%), seed $(10.8 \%)$ and entire plant (8.8\%). These herbal remedies were administered orally, nasally, ocular and topically. As a conclusion, pastoralists and traditional healers in Afar region have immense indigenous knowledge and practices of treating sick animals which should be supported by scientific techniques for analyzing the active ingredients contained in each plant species and for evaluating the safety, efficacy and dosage of the commonly used medicinal plants. In addition, on station establishment of commonly used medicinal plant nursery for conservation purpose and to conduct in-depth phytochemical analysis is paramount important.
\end{abstract}

Key Words: Afar, Camel, Ethnoveterinary, Herbal remedies, Pastoralist, Traditional healers 


\section{INTRODUCTION}

In Ethiopia, as in most dry lands of Africa and Asia, camels are the principal source of income and food for millions of pastoralists(Kaskous, 2016). The major advantages of camels for pastoralists are transportation and as reliable source of milk and meat production. In spite of the valuable economic contribution to the pastoral communities, as well as to the National Gross Domestic Product (NGDP), little effort has made so far to address the constraints of camel production in Ethiopia. A number of studies conducted to indicate camel production constraints shows that, diseases are the major challenges faced by camel raring communities in East Africa (Tekle and Abebe, 2001)

But even if the diseases have been the main causes for under performance of camel population, pastoralists were trying to solve this problem by treating their camel using their cultural knowledge bases and medicinal plants beside to using the Modern medicine. EVM is a scientific term for traditional animal health care that encompasses knowledge, belief, practice and skill of the community used for curing diseases and maintaining health of animals (Adnan M et al., 2014; McCorkle CM and Green EC, 1998). Due to this traditional practices and knowledge; plants have played a central role in combating many ailments in human and livestock in many indigenous communities, including Africa (Bussmann et al., 2011).

In Africa, detailed knowledge of traditional medicine is transferred orally from one generation to the next through professional healers, knowledgeable elders and/or ordinary people (Mirutse Giday et al., 2007). In developed and developing countries, medicinal plants are in greater demand both as a source of primary health care owing to their attributes of having a wide biological activity, high safety margins and lesser costs. In countries like China, India, Africa and South America, the use of herbal medicine continues to present day. In Ethiopia, the primary healthcare of $90 \%$ of the livestock populations depends on plant based traditional medicines (Fullas F, 2007). However, the ethno veterinary practice is affected by acculturation and depletion of plant habitats as a result of environmental degradation, deforestation and over exploitation of the medicinal plants themselves (Gidey M and Ameni G, 2003; Yineger H and Yewhalaw D, 2007). Thus, the ethno veterinary practices will be lost unless the useful medicinal plants are conserved and the associated indigenous knowledge is properly documented and analyzed. Therefore, documentation of traditional medicinal plants, knowledge, and practices is fundamental in order to expedite the future discovery of lead molecules from plants. Previously, most ethno botanical surveys 
were performed only through interviewing of the community members(Belayneh et al., 2012). However, the current study was conducted by using traditional healers as sole sources of information with the assumption that they would have sufficient and profound information about the plants and their medicinal use. The abundance of medicinal plants, the value of the associated indigenous knowledge and practices of the traditional healers in Afar region are expected to be high. However, since there was no comprehensive study conducted on the knowledge and practices of traditional healers about EthnoVeterinary medicine in the area, the current study was conducted to reveal and document the traditional medicinal plant knowledge and practices of traditional healers in selected districts of Afar region. Therefore, this study was carried out with the objectives of identification and documentation of major medicinal plants commonly used to treat camel Aliments in Afar region.

\section{Materials and Method}

\subsection{Description of the study area}

Afar National Regional state is located in the eastern part of the country between $390^{\circ} 34^{\prime}$ and $420^{\circ} 28^{\prime} \mathrm{E}$ longitude and $8^{\circ} 49^{\prime}$ and $14^{\circ} 30^{\prime} \mathrm{N}$ latitude. The total geographical area of the region is about $270,000 \mathrm{~km} 2$ and more than $90 \%$ of the residents of the region are pastoralist. The remaining $10 \%$ are agro-pastoralists. The region is bordered by Eritrea on North-East and with Djibouti on the East, with Tigray Regional state on the North-West, with Amhara Region on the South-West and with Oromia Region on the South and with Somali Region on the South East of Ethiopia (Tekle et al., 2019).

The region is characterized by arid and semi-arid climate with low and inconsistent rainfall. The temperature of the region vary from $20^{\circ} \mathrm{C}$ in higher elevations to $48^{\circ} \mathrm{C}$ in lower elevations with an altitude ranging from $120 \mathrm{~m}$ below sea level to $1500 \mathrm{~m}$ above sea level. Rainfall is bi-modal throughout the region with a mean annual rainfall below $500 \mathrm{~mm}$ in the semi-arid western escarpments and decreasing to $150 \mathrm{~mm}$ in the arid zones to the East. Based on the 2017

projections by the Central Statistical Agency of Ethiopia (CSA), the region has a total population of 1.8 million and administratively, divided into five zones, which are further subdivided into 34 woredas (administrative districts) and 358 pastoral associations (Tekle et al., 2019). 


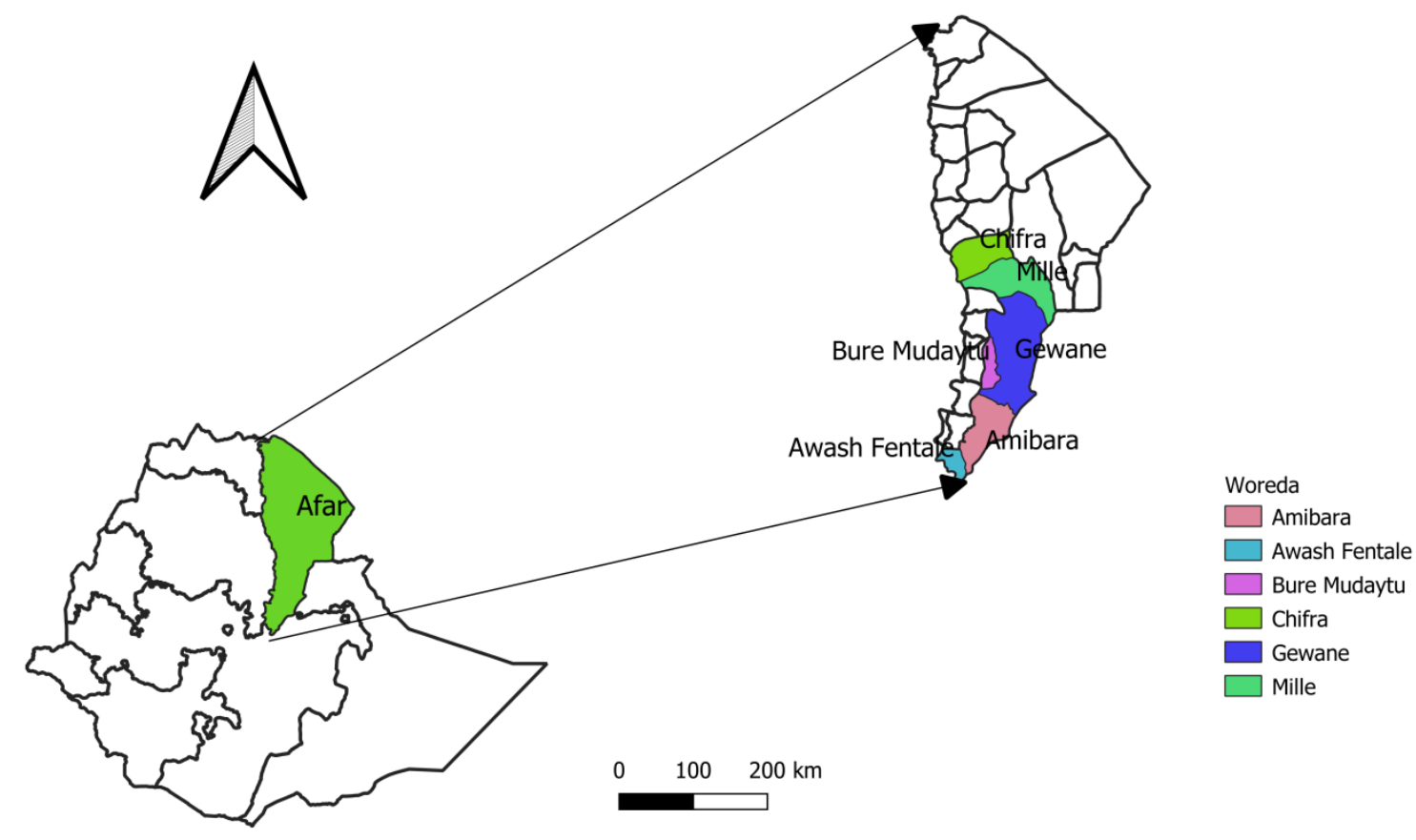

Figure 1: Map showing the study districts

\section{Source: Diva GIS}

\section{Study design and selection of the study participants}

A cross-sectional study was conducted using semi-structured questionnaires from 2016 to 2017 to gather information on the knowledge, practice and skill of the traditional healers about the importance and application of Ethno-veterinary medicine.

Study districts were selected based on their relative potential of livestock production, accessibility to road infrastructure and nearness to Werer agricultural research center. A purposive sampling was employed to recruit camel owners (pastoralists) believed to have enough experience and knowledge about medicinal plants in order to collect the necessary and relevant information. Random sample would not have been appropriate for this type of socio-cultural setup, as not everyone sampled randomly may have the required knowledge(Wanzala et al., 2012). 
Age of the respondent was an important component which was decided to be adult considering that they will get exposure opportunity to Ethno-botanical remedies and traditional treatment method as they get old and also the elders pass their knowledge and experience to one of their family members after maturity. Before starting the interview and discussion, informed consent was obtained from every traditional healer. A total of 146 traditional healers were interviewed with semi structured questionnaire. The questionnaire included questions about the most common diseases in the study area, the treatment measures taken, their knowledge of herbal medicine, parts of plants used and the preparation of plant-based medicines. The interview was conducted in Afarigna language by using translator to collect clear and basic information about indigenous knowledge of EVM.

\section{Plant sample collection and identification}

In the current study 64 Ethno-botanical plant samples were collected from Awash Fantale, Amibara, Burimudayto, Gewane, Mille and Chifra Woredas. Different parts of medicinal plant samples were collected based on their requirement for identification and fixed properly to avoid decay and to maintain the normal morphology of the plant which helps to minimizing confusion at the time of classification. Well-made rubber block and newspaper were used to fix and transport the plant sample. Additionally, plant samples were allowed to dry only by air without exposure to sunlight to keep the plant green throughout. Finally, the collected plant samples were submitted to Addis Ababa University National Herbarium Museum for botanical classification.

\section{Data analysis}

Microsoft excel spread sheet was employed to summarize and SPSS 20 was used to analyze the data. Table and bar graph were used to present data. Fidelity level (FL) and preference raking techniques was performed in the present study to identify the most preferred plant species used for the treatment of certain disorder. So, the most preferred medicinal plant species by traditional healers to treat certain disorder are identified by these techniques. The widely used medicinal plants by traditional healers have higher FL values than those that are less popular. Fidelity level shows the percentage of informants claiming the use of a certain plant species for the same major 
purpose and was estimated using the formula $\mathrm{FL}=\mathrm{Np} / \mathrm{N} \times 100$, where $\mathrm{Np}$ is the number of respondents who reported the utilization of medicinal plants for a specific main ailment and $\mathrm{N}$ is the total number of respondents who mentioned the same plant for any ailment (Negesse.M et al, 2017).

It is assumed that those medicinal plants which are used in some repetitive manner for the same disease category are more likely to be biologically active Preference ranking was conducted for most important medicinal plants used in treating most frequently occurring diseases in the pastoral area according to the traditional healers in the study area (Martin, 1995).

\section{3-RESULT}

Among 146 respondents, $99.3 \%$ of the study participants were male. $66.44 \%$ of the respondents were in the range of 45-60 years. Majority of the participants were from Gawane (24.7\%) and Awash Fantale (22.6\%) district where as only $11 \%$ of total interviewed from Mille.

Table 1: Demographic characteristics of Traditional healers

\begin{tabular}{llll}
\hline Factors & category & Number of TH & $\%$ \\
\hline Age & $30-45$ & 49 & 33.56 \\
& $45-60$ & 97 & 66.44 \\
& Male & 145 & 99.3 \\
Marital status & Female & 1 & .7 \\
& Married & 146 & 100 \\
Woreda & Others & 0 & 0 \\
& Awash Fantale & 33 & 22.6 \\
& Amibara & 21 & 14.4 \\
& Burimudayto & 18 & 12.3 \\
& Gawane & 36 & 24.7 \\
& Mille & 16 & 11 \\
\hline
\end{tabular}

TH: -Traditional healers 
Table 2: Status of Ethno-veterinary medicinal practice in pastoral community of Afar region

\begin{tabular}{|c|c|c|c|}
\hline Factor & Category & Number TH & Percentage $(\%)$ \\
\hline \multirow{4}{*}{$\begin{array}{l}\text { Practice of Traditional } \\
\text { medicine }\end{array}$} & Very well practiced & 11 & 7.53 \\
\hline & Well-practiced & 49 & 33.56 \\
\hline & Moderately practiced & 80 & 54.8 \\
\hline & Not practiced at all & 6 & 4.1 \\
\hline \multirow{2}{*}{$\begin{array}{l}\text { Status of EVM over } \\
\text { the past } 20 \text { years }\end{array}$} & Increasing & 22 & 15.06 \\
\hline & Decreasing & 124 & 84.93 \\
\hline \multirow{5}{*}{$\begin{array}{l}\text { Source of tradition } \\
\text { Ethno veterinary } \\
\text { practice. }\end{array}$} & Elders & 111 & 76.02 \\
\hline & Traditional Healers & 19 & 13.04 \\
\hline & Elders and traditional & 14 & 9.6 \\
\hline & healers & & \\
\hline & Self (trial and error) & 2 & 1.4 \\
\hline \multirow{3}{*}{$\begin{array}{l}\text { Preference of pastoral } \\
\text { society to treat sick } \\
\text { camel }\end{array}$} & Traditional Medicine & 15 & 10.27 \\
\hline & Modern medicine & 61 & 41.8 \\
\hline & Both & 70 & 47.9 \\
\hline
\end{tabular}

Note: EVM=Ethno Veterinary Medicine

It was indicated that, the overall EVM practice and status in the pastoral society of Afar is decreasing over the past 20 years $(84.93 \%)$. Majority of the information's about ethno-veterinary medicine practice were obtained from the elders (76.02\%). EVM practices play an important role for treating sick animals and consequently herbal medicine is their second option where veterinary clinic is inaccessible according to the result of the current study. 
Table 3: The major medicinal plants with respective scientific name, local names and part used base on their frequency

\begin{tabular}{llll}
\hline Botanical name & Local name & Part used & FL (\%) \\
\hline Balanites aegyptia & Udda & bark & 32.47 \\
Cissus rotundifolia (Forssk.) Vahl & Aleae & roots & 22.07 \\
Cadaba rotundifolia Forssk. & Angelita/Adangelita/ & Leaf & 17.53 \\
Solanum sp. & Coasso/Umbo-Coasso & fruit & 12.98 \\
Acalypha indica L. & Baroberbere & Entire plant & 11.68 \\
Tamarix aphylla (L.) Karst. & Muyayto & leaf & 11.03 \\
Aerva javanica & Oliyayto & root & 7.792 \\
Salvadora persica & Adayto & root & 7.14 \\
Citrullus lanatus & Da'artaba & fruit & 6.49 \\
Balanites rotundifolia (van Tieghem) & Alayto & leaf & 5.84 \\
Blatter & & & \\
Acacia oerfota (Forssk.) Schweinf & Gerento & leaf & 5.84 \\
Euphorbia sp. & Ingidato & Entire plant & 5.84 \\
Cucumis aculeatus Cogn & Wokriway & Fruit & 5.84 \\
Celosia polystachia (Forssk.) C.C. & Gobadotoysa & Entire plant & 5.195 \\
Townsend & & & \\
Solanum sp. & Kurarayi/Askurarai & fruit & 5.195 \\
Ziziphus spina-christi (L.) Desf. & Kusura & leaf & 5.195 \\
Cissus quadrangularis L. & Musuruga & leaf & 5.195 \\
Acacia seyal DelAloe trichosantha & Keselto & fruit & 4.55 \\
Berger. & & & \\
Aloe trichosantha Berger & Ureyta & Entire plant & 4.55 \\
\hline
\end{tabular}

In this study, a total of 710 plant species (140 from Amibara, 150 from Awash Fantale, 98 from Burimudayto, 109 from Chifra, 143 from Gawane and 70 from Mille) were recommended by traditional healers and elders to be used for the treatment of more than 49 different animal aliments. In addition, it was also appreciated that a single plant species can be used to treat different type of animal diseases whereas different part of the medicinal plants is used for the treatments of different diseases. 
Table 4: Commonly prevalent camel diseases and respective medicinal plants in the pastoral society of Afar region

\begin{tabular}{|c|c|c|c|}
\hline $\begin{array}{l}\text { Name of the } \\
\text { Disease }\end{array}$ & $\begin{array}{l}\text { Medicinal plants used to treat the } \\
\text { disease }\end{array}$ & $\begin{array}{l}\text { Parts of the } \\
\text { plant used }\end{array}$ & $\begin{array}{l}\text { Solvent/ingredi } \\
\text { ent added. }\end{array}$ \\
\hline Local Abscess & Balanites aegyptia & bark & water \\
\hline Tuberculosis & Citrullus lanatus & roots & water \\
\hline $\begin{array}{l}\text { Weakened } \\
\text { immunity }\end{array}$ & Tamarix aphylla (L.) Karst. & Entire plant & water \\
\hline Eye diseases & Solanum sp. & fruit & - \\
\hline Anthrax & Aerva javanica and Galayito & Root & - \\
\hline Itching & $\begin{array}{l}\text { Acacia seyal DelAloe trichosantha } \\
\text { Berger. }\end{array}$ & fruit & Water \\
\hline Diarrheoa & Balanites aegyptica & Root & Water \\
\hline Pneumonia & Cissus rotundifolia (Forssk.) Vahl & leaf & water \\
\hline prophylaxis & Tobacco & Leaf & - \\
\hline eye infection & Aerva javanica & roots & - \\
\hline $\begin{array}{l}\text { mange mite } \\
\text { Camel ox }\end{array}$ & $\begin{array}{l}\text { Acacia oerfota (Forssk.) Schweinf } \\
\text { pepper }\end{array}$ & fruit & - \\
\hline Mastitis & Detatut & Root & water \\
\hline $\begin{array}{l}\text { Fly infestation, } \\
\text { Weak } \\
\text { offspring }\end{array}$ & $\begin{array}{l}\text { Cadaba rotundifolia Forssk. } \\
\text { Tobacco leaf }\end{array}$ & $\begin{array}{l}\text { Leaf } \\
\text { leaf }\end{array}$ & Water \\
\hline Tick infestation & $\begin{array}{l}\text { Aloe trichosantha Berger and } \\
\text { Cadaba rotundifolia Forssk. }\end{array}$ & Steam & Water \\
\hline $\begin{array}{l}\text { Plant } \\
\text { poisoning }\end{array}$ & Ziziphus spina-christi (L.) Desf. & Leaf & water \\
\hline
\end{tabular}

Table 4 indicates the most commonly occurring camel diseases which can be treated traditionally by medicinal plant remedies. Based on this, the disease which is called Galidele(local abscess) stands first in the table followed by Tuberculosis, Weakened immunity and Eye disease. 
Table 5: Preference ranking of six medicinal plants for the treatment of Galidele (topical Abscess)

\begin{tabular}{lllllllll}
\hline List of Medicinal plant & R1 & R2 & R3 & R4 & R5 & R6 & Total & Rank \\
\hline Balanites aegyptia & $\mathbf{1 2}$ & $\mathbf{6}$ & $\mathbf{5}$ & $\mathbf{0}$ & $\mathbf{5}$ & $\mathbf{1}$ & $\mathbf{2 9}$ & $\mathbf{1}^{\text {st }}$ \\
Cissus rotundifolia (Forssk.) Vahl & $\mathbf{1 2}$ & $\mathbf{1 4}$ & $\mathbf{0}$ & $\mathbf{0}$ & $\mathbf{0}$ & $\mathbf{0}$ & $\mathbf{2 6}$ & $\mathbf{2}^{\text {nd }}$ \\
Acalypha indica L & $\mathbf{0}$ & $\mathbf{0}$ & $\mathbf{2}$ & $\mathbf{0}$ & $\mathbf{5}$ & $\mathbf{0}$ & $\mathbf{7}$ & $\mathbf{3}^{\text {rd }}$ \\
Aerva javanica & $\mathbf{0}$ & $\mathbf{0}$ & $\mathbf{1}$ & $\mathbf{0}$ & $\mathbf{0}$ & $\mathbf{0}$ & $\mathbf{1}$ & $\mathbf{4}^{\text {th }}$ \\
Euphorbia sp. & $\mathbf{0}$ & $\mathbf{0}$ & $\mathbf{0}$ & $\mathbf{0}$ & $\mathbf{0}$ & $\mathbf{0}$ & $\mathbf{0}$ & - \\
Acacia seyal Delaloe & $\mathbf{0}$ & $\mathbf{0}$ & $\mathbf{0}$ & $\mathbf{0}$ & $\mathbf{0}$ & $\mathbf{0}$ & $\mathbf{0}$ & - \\
\hline
\end{tabular}

R1-R6 represents Respondents

In this study it was also appreciated that, the pastoral community of Afar region were used to treat their animals by using different medicinal plants for each disease. The reason behind this is that, as the pastoral society resides in the different parts of the region, they use different skill and knowledge about usage of herbal medication to treat any ailment. They also use different approach and preparation methods of herbal medicine. 


\section{Plant parts used and condition of remedy preparation}

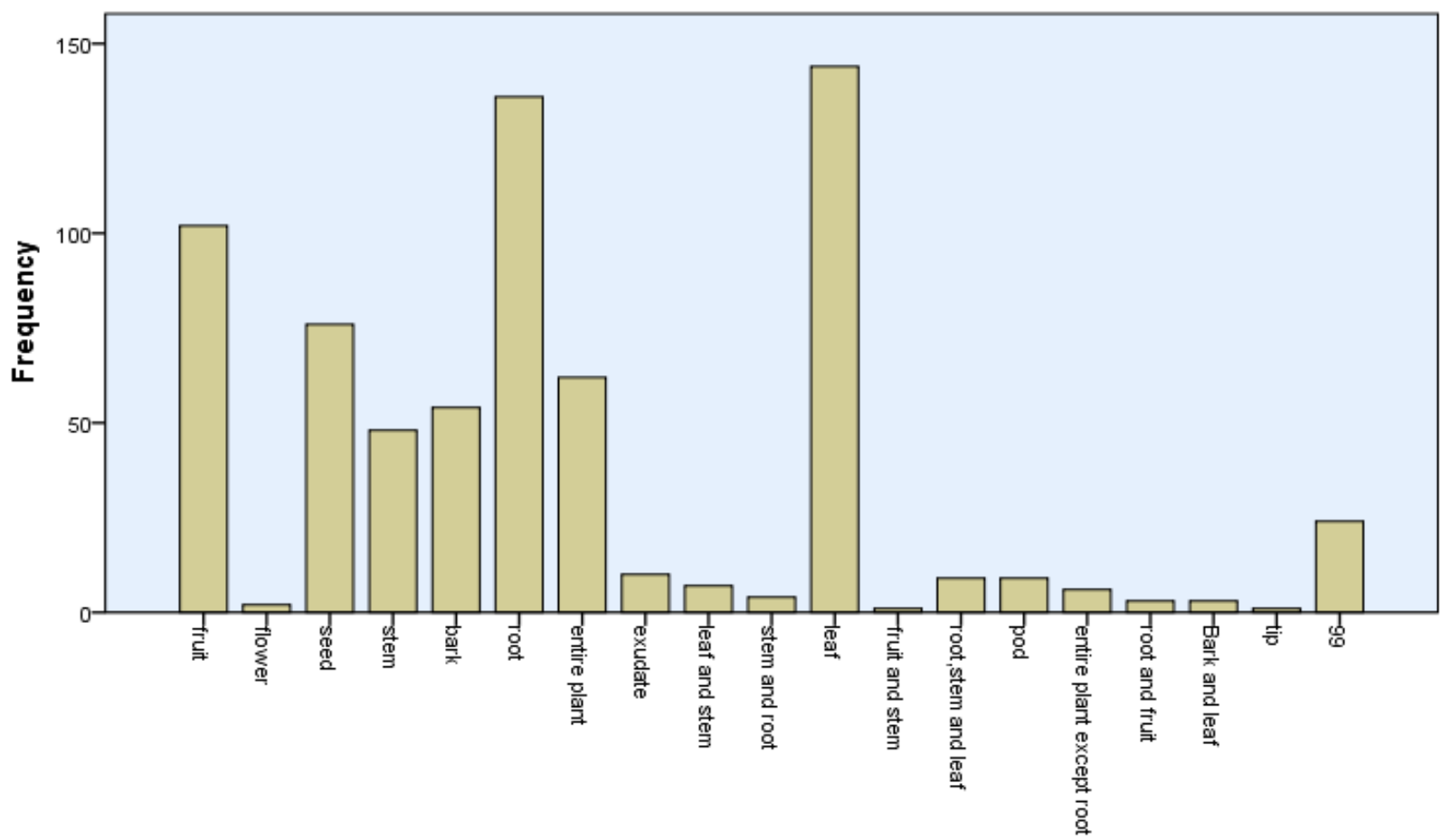

Figure 1:-Parts of medicinal plant used

In the current study, leaf $(20.5 \%)$ was the most frequently used plant parts followed by root (19.4\%), fruit (14.4\%), seed (10.8\%) and entire plant (8.8\%) (Figure 1). Different additives such as water, butter, salt, pepper and milk were frequently used in the preparation of plant remedies so as to improve the flavor, to decrease the toxicity of the remedies, to prepare suitable formulations and to simplify the administration of the medicinal remedies. The major preparation methods of these medicinal remedies are chopping/grinding and soaking it into the water followed by removal of the debris and supplying the remained juice mixture to the sick animals. In addition, sick animals can also feed fresh plant if it has a good palatability. Some people also believe that, the animals can recover if certain medicinal plant which is supposed to be curative for each disease is tied to the tail of the sick animal.

The overall fidelity level value analysis of the most frequently used traditional medicinal plants against different disease condition indicated that, Balanites aegyptia was found to have the highest value followed by Cissus rotundifolia (Forssk.)Vahl which is used for the treatment of local abscess. 
On the other hand, this study showed that, preference ranking of six medicinal plants used for the treatment of topical abcess showed that Balanites aegyptia was the most preferred plant, followed by Cissus rotundifolia (Forssk.) Vahl and Acalypha indica L (Table 5). The prognosis of the sick animals after being treated by using herbal remedies is good based the response of traditional healers. But in some animals the best prognosis can be sought based on the preparation methods and route of admiration.

\section{Discussion}

In the present study, majority of the traditional healers were between 45-60 years old. In the pastoral society of Afar region, males usually start dealing with animals from their childhood. However, they will gain a comprehensive know-how about traditional medicine at their adulthood and when they take the responsibility of leading the household since it is considered as a professional secret endorsed from their ancestor. The gender distribution of medicinal plant knowledge indicated that among those traditional healers involved in the study, $99.3 \%$ were males while (0.7) was females. Similar findings were reported in a study done in Jimma zone of Ethiopia by (YaredYigezu et al., 2014), in Karak district of Pakistan by (Murad et al., 2013) and in Harar, Haramaya, Bati and Garamuleta in Ethiopia by (Negesse Mekonnen and Endalkachew Abebe,2017). This might be due to the fact that, females in pastoral society of Afar region are restricted only to deal with house issue such as house construction, caring for the children, food preparation, milking cattle and churning it and so on. On the other hand, male family members are responsible for raring and caring for animals, take them to the area with sufficient water and feed resource, protecting from being attacked by wildlife, treat/ inform to the traditional healers when the animals get sick. Because of these and other reasons, female will not gain chance to know about traditional treatment and herbal medicine. The bad habits and traditions which restrict females to house activities (like caring for babies, cooking food, etc.) and hence lack contact with the environment and knowledgeable individuals might be responsible for the discrepancy in the gender distribution of Ethno veterinary medicinal knowledge (Yihenew Simegniew et al., 2017). 
In the present study, majority of the traditional healers are illiterate and only few of them have attended the primary education based on the informal communication. This is due their mobile life style which is not suitable to attend school and lack of educational infrastructure in the area. Similar finding was also reported by Mirutse Giday et al., (2009) that, people who can read and write had insufficient knowledge of traditional medicine which might be the impact of modern education and information to traditional medicine. Additionally, the usage of herbal remedies in the Afar region is decreasing due to intensification of modern knowledge and wide spread occurrence of drought. This two major reason enforced the pastoralist to shift their preference to modern medicine rather than using herbal remedies. Even though the preference of the pastoralists is shifting toward the usage of modern medicine, society in living in remote and inaccessible area still rely on herbal remedies to treat sick animals

In the present study, about 710 medicinal plants and different ingredients were recommended to be used for the treatment of more than 49 animal diseases. Similar ethno-veterinary surveys conducted in Ada'ar District of Afar Region by Giday M,2013 and Teklehaymanot, (2013), in Dabo Hana district of Borena Zone by Tamiru F et al., (2013), in selected four districts of Jimma zone by Yigezu Y et al., (2013), in Ankober district of North Shewa zone by Lulekal E et al., (2014) documented 49, 106, 74 and 51 medicinal plant species respectively. These findings clearly indicated the importance of plant based ethno-veterinary remedies in the management of livestock disease in different regions of Ethiopia. In the present study, the recommended medicinal plants were much greater in number due to various reasons. Lifestyle, inaccessibility of modern medicine and the natural characteristics of shrubs are among the major reason which enforced the pastoral to know and use many different plants as herbal medicine. On the other hand, water shortage in this area can enable many plants species to have medicinal characteristics.

Previous laboratory and clinical trial studies conducted in different parts of the world indicated the activity of Balanitaceae which is also reported in the present study. Balanites aegyptica was reported to be used for the treatment of Jaundice, intestinal worms, malaria, diarrhea and abdominal ache. Fortunately, the family Balanitaceae is the most frequently used medicinal plant family by traditional healers in the current study. 
The most widely used plant part in the preparation of remedies were the leaves $(20.5 \%)$, followed by root and fruit with $19.4 \%$ and $14.6 \%$ respectively. This finding is in consistent with the report of different researchers in Ethiopia and elsewhere (Abera, 2014; Belayneh et al., 2012; Chekole et al., 2015; Enyew et al., 2014). The good reason why plant leaves are the most frequently used in the extraction of pharmacologically active ingredients for the treatment of different ailments is that, leaves contain many metabolites with anti-illness effects (Negesse Mekonnen, 2017) and Mekonnen Abebe, 2017). Besides to this, harvesting of leaves compared to roots, stem and whole plants has minimum negative impact on the survival and continuity of important medicinal plants and hence does not affect the sustainable utilization of the plants (Haile, 2017). Most of the ethno veterinary practitioners in the present study reported that, they prefer fresh plant materials to prepare effective and efficient remedies (Yihenew Simegniew et al., 2017). The use of fresh plant materials for remedy preparations is also well documented elsewhere in Ethiopia (as most of the bioactive chemicals are retained in fresh plant materials as compared to dry ones.

Concerned with route of administration, oral was the most frequently used accounting for $34.4 \%$ followed by Nasal (18.5\%). Different studies from other parts of Ethiopia also reported oral as the preferred route of remedy application. The more preference of oral route for remedy application could be due to the immediate onset of action and sustained physiological effects. Contrary to this finding, Yirga et al., (2012) reported dermal as the principal route of ethnoveterinary remedy administration in Seharti Samre district of northern Ethiopia. Even though a considered number of pastoral communities prefer to use herbal medicines for the treatment of sick animal's, lack of standard dosage and precise measurement are its common drawbacks (Abebe D and Ayehu A, 2015).

For the preparation of herbal remedies, different solvents/ingredients were used. Among these, water is the most commonly used solvent and followed by the use of salt, butter and pepper. The healers believed that crushing and soaking the herbal remedies into different solvents or ingredients will enhanced its efficacy. Healers explained that, the use of such solvents would extract the active compounds which are comparable to the modern phytochemical extraction techniques. Moreover, additives were used to improve the flavor as it was documented in similar findings reported by study done in different parts of Ethiopia (Chekole et al., 2015; Megersa et 
al., 2013; Yigezu et al., 2014). In this study the overall fidelity level value analysis of the most frequently used traditional medicinal plants against different disease condition indicated that, Balanites aegyptia was found to have the highest value followed by Cissus rotundifolia (Forssk.) Vahl which is used for the treatment of local abscess. On the other hand, this study showed that, preference ranking of six medicinal plants used for the treatment of topical abcess showed that Balanites aegyptia was the most preferred plant, followed by Cissus rotundifolia (Forssk.) Vahl and Acalypha indica L.

\section{Conclusion}

This study suggested that traditional healers in Afar region have incredible and comprehensive ethno botanical knowledge and practices. The use of traditional healers and pastoralist as a primary source of information provider in ethno-botanical survey permitted to document adequate and in-depth information. In this study, ethno-botanical knowledge, practices and 710 species of medicinal plants that have been used for the treatment of more than 49 types of major animal ailments were documented. So, the indigenous knowledge and practices of traditional healers in Afar region should be supported by scientific methods to evaluate the safety, efficacy and dosage of the commonly reported medicinal plants. In addition, on station establishment of commonly used medicinal plant nursery for conservation purpose and to conduct in-depth phytochemical analysis is paramount important. 


\section{REFERENCE}

Abebe D, Ayehu A,1993. Medicinal plant and enigmatic health practices of north Ethiopia. Addis Ababa, Ethiopia. Berhanina Selam Printing Enterprise 46.

Birhanu T, Abera D.Survey of ethno-veterinary medicinal plants at selected Horro Gudurru Districts, Western Ethiopia. Afr J Plant Sci. 2015; 9: 185-192.

Abera, B., 2014. Medicinal plants used in traditional medicine by Oromo people, Ghimbi District, Southwest Ethiopia. J. Ethnobiol. Ethnomed 10:1-15.

Adnan M, Ullah I, Tariq A, Murad W, Azizullah A, Khan A.,2014. Ethnomedicine use in the war affected region of Northwest Pakistan. J Ethinobiol Ethinomed. 10: 16

Bussmann, W. R., Swartzinsky, P., Worede, A. and Evangelista, P., 2011. Plant use in Odo-Bulu and Demaro, Bale region Ethiopia. J. Ethnoboil. Ethnomed.7: 28.

Chekole, G., Asfaw, Z., And, E.K.-J. of ethnobiology, 2015, U., 2015. Ethnobotanical study of medicinal plants in the environs of Tara-gedam and Amba remnant forests of Libo Kemkem District, northwest Ethiopia. Springer 11(1):4.

Enyew, A., Asfaw, Z., Kelbessa, E., Nagappan, R., 2014. Ethnobotanical study of traditional medicinal plants in and around Fiche District, Central Ethiopia. Curr. Res. J. Biol. Sci 6: 154-167.

Fullas, F., 2007. The role of indigenous medicinal plants in Ethiopian healthcare. African Renaiss 4:76-80.

Giday, M., Teklehymanot, T., Abebe, A. and Yalemtsehay, M., 2007. Medicinal plants of the Shinasha, Agew-awe and Amhara peoples in northwest Ethiopia. J. Ethno. Pharmacol. 110:516-525.

Giday M, Teklehaymanot T.,2013. Ethnobotanical study of plants used in management of livestock health problems by Afar people of Ada'ar District, Afar Regional State, Ethiopia. J Ethnobiol Ethnomed.; 9: 8

Gidey M, Ameni G., 2003. An ethnobotanical survey on plants of veterinary importance in two Weredas of Southern Tigray, Northern Ethiopia SINET. Ethiop J Sci.; 26: 123-136.

Haile, Z., 2017. Ethno-botanical investigation of medicinal plants use by oromo people in middle altitudes at limu kosa woreda, jimma zone.PhD dissertation

Kaskous, S., 2016. Importance of camel milk for human health. Emirates J. Food Agric. 158163. 
Lulekal E, Asfaw Z, Kelbessa E, Damme PV., 2014. Ethnoveterinary plants of Ankober District, North Shewa Zone, Amhara Region, Ethiopia. J Ethnobiol Ethnomed. 10: 21.

Martin, G.J., 1995. Ethnobotany; a method Manual Chap mart and Hall.

McCorkle CM, Green EC.,1998. Intersectoral health care delivery. Agric Hum 15: 105-114.

Megersa, M., Asfaw, Z., Kelbessa, E., Beyene, A., Woldeab, B., 2013. An ethnobotanical study of medicinal plants in Wayu Tuka district, east Welega zone of oromia regional state, West Ethiopia. J. Ethnobiol. Ethnomed 9:68.

Mekonnen, N., Abebe, E., 2017. Ethnobotanical knowledge and practices of traditional healers in

Harar, Haramaya, Bati and Garamuleta, Eastern Ethiopia. Ethiop. Vet. J. 21:40-61.

Negesse Mekonnen and Endalkachew Abebe 2017: Ethnobotanical knowledge and practices of traditional healers in Harar, Haramaya, Bati and Garamuleta, Eastern Ethiopia. Ethiop. Vet. J., 21 (2): 40-61

Tamiru F, Terfa W, Kebede E, Dabessa G, Roy RK, Sorsa M.,2013. Ethnoknowledge of plants used in veterinary practices in Dabo Hana District, West Ethiopia. J Med Plants Res., 7: 2960-2971.

Tekle, T., Abebe, G., 2001. Trypanosomosis and helminthoses: major health problems of camels (Camelus dromedarius) in the Southern Rangelands of Borena, Ethiopia. J. Camel Pract. Res. ,8: 39-42.

Wanzala, W., Takken, W., Mukabana, W.R., Pala, A.O., Hassanali, A., 2012. Ethnoknowledge of Bukusu community on livestock tick prevention and control in Bungoma district, western Kenya. J. Ethnopharmacol.,140: 298-324.

Yineger H, Yewhalaw D.,2007. Traditional medicinal plant knowledge and use by local healers in Sekoru District, Jimma Zone, Southwestern Ethiopia. J Ethnobiol Ethnomed.,3: 24.

Yigezu Y, Haile DB, Ayen WY.,2014. Ethnoveterinary medicines in four districts of Jimma zone:cross sectional survey for plant species and mode of use. BMC Vet Res.; 10: 76.

Yihenew Simegniew Birhan, Sintayehu Leshe Kitaw, Yihalem Abebe,Alemayehu and Nakachew Minuye Mengesha.,2018. Ethnoveterinary Medicinal Plants and Practices in Enarj Enawga District, East Gojjam Zone, Amhara Region, Ethiopia. International Journal of Animal Science.,2(1):1-4

Yirga G, Teferi M, Gidey G, Zerabruk S.,2012. An ethnoveterinary survey of medicinal plants used to treat livestock disease in Seharti Samre District, Northern Ethiopia. Afr J Plant Sci. .,6: 113-119. 


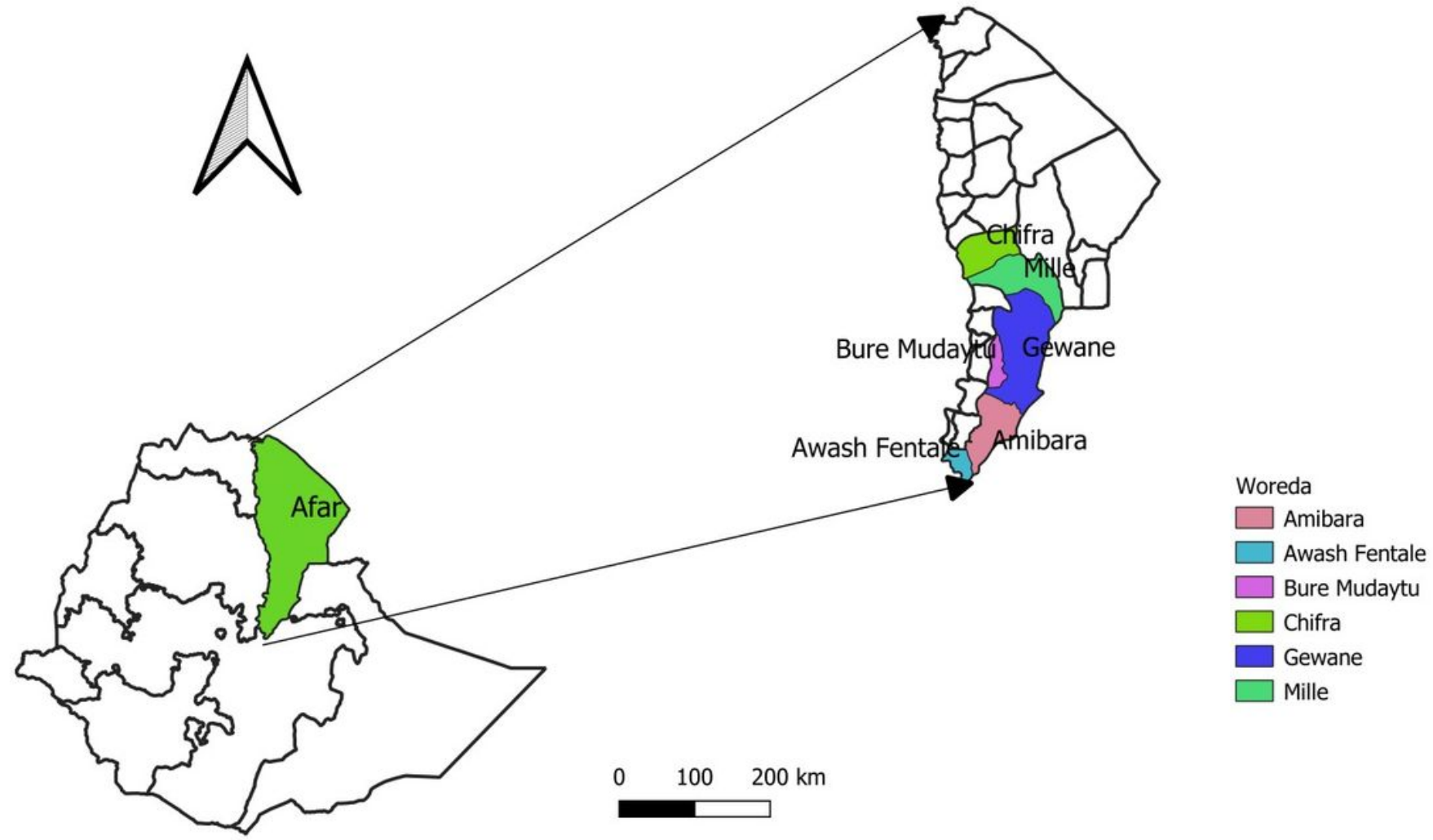

\section{Figure 1}

Map showing the study districts. Note: The designations employed and the presentation of the material on this map do not imply the expression of any opinion whatsoever on the part of Research Square concerning the legal status of any country, territory, city or area or of its authorities, or concerning the delimitation of its frontiers or boundaries. This map has been provided by the authors. 


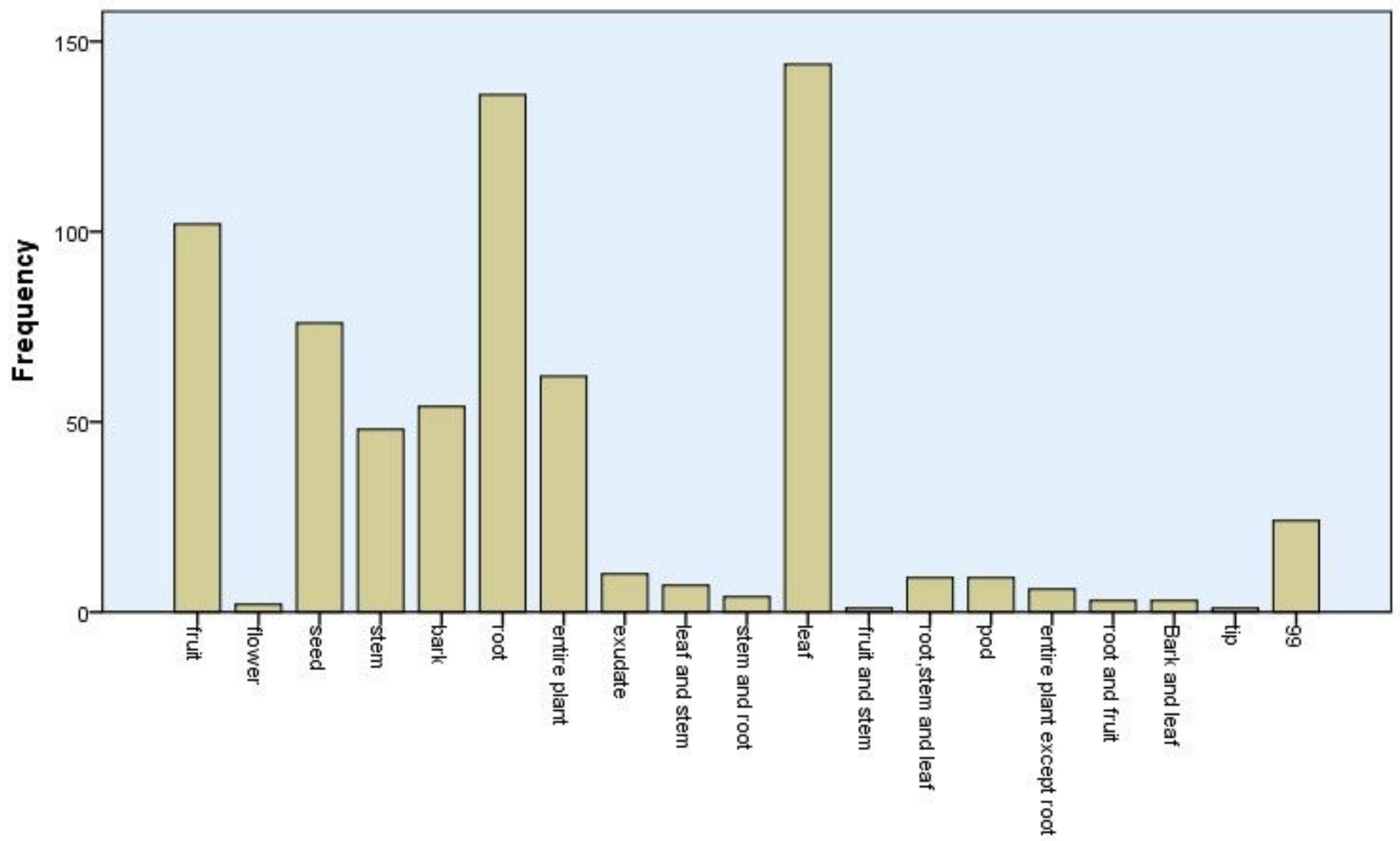

Figure 1:-Parts of medicinal plant used

Figure 2

Parts of Medicinal plant used

\section{Supplementary Files}

This is a list of supplementary files associated with this preprint. Click to download.

- EVMOriginalData.xlsx

- Ethnovetsurveydata.xlsx 